УДК 618.39-021.3-039.70

\title{
І.В. Каліновська
}

\section{ЕХОГРАФІЧНІ ОСОБЛИВОСТІ РОЗВИТКУ ЕМБРІОНА У ВАГІТНИХ З ПЛАЦЕНТАРНОЮ ДИСФУНКЦІЕЮ}

Вищий державний навчальний заклад України «Буковинський державний медичний університет», м. Чернівці

Резюме. У статті наведені ультразвукові критерії розвитку первинної плацентарної дисфункції у вагітних. На основі виділених ультразвукових критеріїв вивчено наслідки та результати вагітності. Із 40 вагітних у $9(22,5 \%)$ при першому ультразвуковому дослідженні виявлене відставання куприко-тім'яного розміру (КТР) ембріона більш ніж на два тижні гестації. Слід зазначити, що в чотирьох із даних спостережень при КТР ембріона менше 18 мм усі вагітності закінчилися мимовільним викиднем. У той же час при КТР більше

Вступ. Незважаючи на значну кількість наукових робіт, спрямованих на вивчення етіопатогенезу плацентарної недостатності, ця проблема й досі залишається однією 3 найбільш складних серед акушерської патології. На сьогодні існує багато методик діагностики та лікування плацентарної недостатності у вагітних із застосуванням широкого кола препаратів. Але, незважаючи на це, частота даної патології продовжує зростати, залишаючись провідною патогенетичною ланкою репродуктивних невдач $[1,2]$. Саме тому подальше вивчення тих складних та мультисистемних процесів, що відбуваються в організмі жінок із проявами плацентарної недостатності вже в ранні гестаційні терміни, особливостей формування фетоплацентарного комплексу, $\epsilon$ актуальним i сприятиме зменшенню частоти акушерської та перинатальної патології[3,4]. Тому дослідження ехографічних змін у вагітних із проявами плацентарної недостатності в першому триместрі вагітності має важливе прогностичне значення.

Мета дослідження. Вивчити особливості росту і розвитку плідного яйця та плода у вагітних із проявами плацентарної недостатності та невиношуванням вагітностей в анамнезі.

Матеріал і методи. Для виконання поставленої мети проведено ультразвукове дослідження 40 вагітних із проявами плацентарної недостатності в першому триместрі вагітності. Вік обстежених складав від 17 до 38 років. Першовагітних було 16 (40 \%), повторновагітних - 24 (60\%). Супутні захворювання спостерігались у 17 жінок (42,5\%), анемія І ступеня - у 8 жінок (20\%), дифузний зоб І ступеня - у 4 жінок $(10,0 \%)$, хронічний гастродуоденіт - у 3 жінок $(7,5 \%)$ хронічний пієлонефрит - у 6 жінок (15,0 \%).

Ретроспективний аналіз показав, що у вагітних досліджуваної групи в 82,3 \% спостерігались явища загрози переривання вагітності та в $52 \%$ у попередніх вагітностях. У 69,1 \% досліджених вагітних в анамнезі були мимовільні викидні в терміні до 13 тижнів, а також у 13,5 \% пізні мимовільні викидні в терміні 22-25 тижнів. У 34,5 \%
18 мм у жодному спостереженні (5) не відбулося мимовільного переривання вагітності. Значення КТР ембріона найбільш інформативні для прогнозу перебігу і результату гестаційного процесу в першому триместрі вагітності. Брадикардія ембріона/плода $є$ ультразвуковою ознакою, що вказує на можливість патологічного результату гестаційного процесу в жінок зі звичною утратою вагітності, так і з проявами плацентарної недостатності.

Ключові слова: ембріон, брадикардія, тахікардія, плідне яйце.

жінок вагітність супроводжувалася кровомазанням у ранньому ембріональному періоді та частковим відшаруванням хоріона. У 16,2 \% випадків вагітних в анамнезі були відмерлі вагітності в терміні до 10 тижнів.

3 метою виявлення особливостей росту та розвитку плідного яйця в першому триместрі вагітності під час ультразвукового дослідження проводилася оцінка структур ембріона, показників серцевої діяльності ембріона та оцінка об’єму ретрохоріальної гематоми.

Результати дослідження та їх обговорення. При спостереженні в 11 (27,5 \%) пацієнток із невиношуванням вагітності в анамнезі виявлено відставання КТР від очікуваних значень на 6-10 днів. При повторному ультразвуковому скануванні, виконаному через два тижні, у 9 (22,5\%) спостереженнях відзначений позитивний приріст ембріометричних показників і їхня відповідність гестаційному терміну. У 3 (7,5 \%) вагітних зберігалося відставання куприко-тім'янного розміру ембріона від гестаційного терміну не більше ніж на сім днів. При динамічному ультразвуковому контролі і проведенні фетометрії відзначене коливання біометричних параметрів плода в нормативних для терміну межах. У той же час, у 7 $(17,5 \%)$ пацієнток прогресуюче зниження КТР ембріона в сполученні зі зменшенням об'єму плодового яйця дозволило діагностувати затримку росту ембріона, що стало клінічним симптомом первинної фетоплацентарной недостатності. Згодом у зазначених спостереженнях діагностовані різні ускладнення гестаційного процесу: нерозвиваюча вагітність - 4 (10,0\%) і мимовільний викидень у терміни до 10 тижнів - 3 (7,5\%).

Із 40 вагітних у $9(22,5 \%)$ при першому ультразвуковому дослідженні виявлене відставання КТР ембріона більш ніж на два тижні гестації. Слід зазначити, що в чотирьох із даних спостережень при КТР ембріона менше 18 мм усі вагітності закінчилися мимовільним викиднем. У той же час при КТР більше 18 мм у жодному спостере-

(C) І.В. Каліновська, 2015 
Таблиця

Ехохрафічні особливовості ембріона при патологічному перебігу гестаційного процесу у паціснток із плацентарною дисфункцією

\begin{tabular}{|c|c|c|c|}
\hline Ехографічна ознака & Частота & Перебіг вагітності & Результат вагітності \\
\hline Відсутність серцебиття при КТР>16мм & $5,71 \%$ & - & $\begin{array}{c}\text { Вагітність, яка не розвивається } \\
(100 \%)\end{array}$ \\
\hline Відставання КТР від терміну на 6-10 днів & $27,5 \%$ & $\begin{array}{c}\text { Без ускладень } \\
4(36 \%)\end{array}$ & $\begin{array}{c}\text { При прогресуванні відставання } \\
\text { КТР: мимовільний викидень } \\
(27 \%) \text { вагітність, що не розви- } \\
\text { вається }(36 \%)\end{array}$ \\
\hline Відставання КТР від терміну на $>14$ днів & $22,5 \%$ & $\begin{array}{c}\text { Загроза переривання } \\
(100 \%)\end{array}$ & $\begin{array}{c}\text { Мимовільне переривання вагіт- } \\
\text { ності (44,4 \%) КТР }<18 \text { мм }\end{array}$ \\
\hline Брадикардія & $10,0 \%$ & $\begin{array}{c}\text { Загроза переривання } \\
(100 \%)\end{array}$ & $\begin{array}{c}\text { Мимовільне переривання вагіт- } \\
\text { ності (100 \%) }\end{array}$ \\
\hline Тахікардія & $12,5 \%$ & Загроза викидня (100 \%) & $\begin{array}{c}\text { Миражевільй тахікардії на тлі вики- } \\
\text { дня, що почався) }(33,3 \%)\end{array}$ \\
\hline
\end{tabular}

женні (5) не відбулося мимовільного переривання вагітності.

Слід зазначити, що відставання ембріометричних параметрів (КТР) діагностувалося нами за наявності загрозливого переривання вагітності. При цьому чітко простежувалася тенденція до поліпшення приросту ембріометричних показників після купірування симптомів загрози викидня.

Таким чином, згідно з отриманим нами результатом, значення КТР ембріона найбільш інформативні для прогнозу перебігу і результату гестаційного процесу в першому триместрі вагітності.

При оцінці показників серцевої діяльності ембріона у групі вагітних зі звичною утратою вагітності в більшості спостережень (70 \%) динаміка змін частоти серцевих скорочень (ЧСС) ембріона відповідала параметрам фізіологічного перебігу вагітності. Так, ЧСС ембріона поступово зростала з шести тижнів гестації (107 \pm 12 уд/хв) до 9-10 тижнів (176 \pm 11 уд/хв), потім до 12 тижнів знижувалася до $159 \pm 6$ уд/хв. Найбільша частота серцевих скорочень (180 уд/хв; $<<0,05)$ так само відзначена в дев'ять тижнів вагітності. Однак у 3 $(5,71 \%)$ спостереженнях при КТР ембріона 14 мм і більше (14-26 мм) нами не зареєстровано серцевої діяльності ембріона, дозволило поставити діагноз вагітності, що не розвивається.

У $9(22,5 \%)$ спостереженнях ЧСС ембріона не відповідала нормативним значенням. Серед вагітних із клінічною картиною загрозливого переривання в 5 (12,5 \%) ембріонів відзначена тахікардія. 3 них у трьох спостереженнях виявлене виражене зростання ЧСС ембріона в межах 190-210 уд/хв на тлі мимовільного переривання вагітності. Зниження частоти серцевих скорочень (брадикардія до 90 уд/хв) виявлене у 4 (10,0\%) пацієнток із клінічною картиною загрозливого мимовільного викидня і діагностованої згодом загибеллю ембріона. Слід зазначити, що в жодному спостереженні хромосомна аномалія ембріона/плода не виявлена.
Порівняння результатів дослідження серцевої діяльності плода в першому триместрі з подальшим перебігом і результатом вагітності встановило, що величина ЧСС має прогностичне значення, насамперед для перших 12 тижнів. Зміни серцевої активності, що спостерігаються нами, свідчили про патологічний перебіг першого триместру вагітності.

Отже, брадикардія ембріона/плода є ультразвуковою ознакою, що вказує на можливість патологічного результату гестаційного процесу в жінок зі звичною втратою вагітності, так і з проявами ПН із діагностичною точністю $91 \%$ і специфічністю 87,6 \%.

Таким чином, при ехографічній оцінці росту і розвитку ембріона в пацієнток із плацентарною недостатністю нами встановлені основні прогностичні критерії несприятливого перебігу і результату вагітності, представлені в таблиці.

Серед обстеженої групи вагітних у 12 (30 \%) при ультразвуковому дослідженні діагностовано наявність ретрохоріальної гематоми в терміні 810 тижнів вагітності. 3 них у 6 (50\%) спостереженнях при ультразвуковому скануванні відзначене корпоральное розташування гематоми, тоді як у $3(25,0$ \%) пацієнток-супрацервікальне. При цьому розмір ділянки відшарування хоріона в 9 (75\%) спостереженнях склав не більше 20 мл (у середньому 14,7 2 2,9 мл).

В інших 3 (25\%) вагітних діагностований великий (більше 20 мл) об'єм ретрохоріальної гематоми в середньому $23,1 \pm 5,8$ мл. При цьому скарги на мажучі кров'янисті виділення зі статевих шляхів протягом одного-двох днів пред'являли 4 (33,3 \%) пацієнтки 3 діагностованою ретрохоріальною гематомою. Разом 3 тим 5 (41,6 \%) пацієнток відмічали наявність періодично виникаючого тягнучого болю внизу живота. При цьому у всіх вагітних із зазначеними скаргами виявлялося підвищення тонуса матки при ультразвуковому дослідженні 1-2-го ступеня. В інших 3 
(25 \%) спостереженнях відзначалося сполучення зазначених симптомів. Зіставлення клінічних симптомів із даними ультразвукової ехографії в жінок із частковим відшаруванням хоріона дозволило виділити наступні особливості перебігу вагітності. Так, симптоми загрози викидня проявлялися болем внизу живота, що найбільш характерне для корпорально розташованої гематоми. У свою чергу, супрацервікальне відшарування хоріона супроводжувалося переважно кров'янистими виділеннями 3 пологових шляхів.

Крім того, аналіз перебігу і результату першого триместру вагітності виявив несприятливе прогностичне значення виявлення корпорального розташування гематоми на відміну від супрацервікального. Велике значення мав об'єм ретрохоріальної гематоми. Аналіз результатів проведеного нами дослідження показував, що в 3 (25\%) спостереженнях, що завершилися мимовільним викиднем, об'єм гематоми перевищував 20 мл і складав від 27 до 35 мл. При цьому в однієї вагітної велика за об'ємом гематома (35 мл) розташовувалася в ділянці проекції кореня пуповини.

Таким чином, за наявності субхоріальної гематоми в завдання ультразвукового дослідження варто включати оцінку місця розташування і розрахунок об’єму ділянки відшарування хоріона.

\section{Висновки}

1. Значення куприко-тім'яного розміру ембріона найбільш інформативні для прогнозу перебігу і результату гестаційного процесу в першому триместрі вагітності.

2. Брадикардія ембріона/плода $є$ ультразвуковою ознакою, що вказує на можливість патологічного результату гестаційного процесу в жінок зі звичною втратою вагітності, так і з проявами плацентарної недостатності.

Перспективи подальших досліджень. У подальшому планується дослідження допплерометричних змін у вагітних за наявності розвитку плацентарної дисфункції.

\section{Література}

1. Бурлака О.В. Рання пренатальна діагностика плацентарної недостатності при звичному невиношуванні вагітності: автореф. дис. на здоб. наук. ступ. канд. мед. наук / О.В. Бурлака. - К., 2012. - 18 с.

2. Грищенко B.I. Актуальні проблеми сучасної перинатології/ В.І. Грищенко , М.О. Щербина, О.В. Мерцалова // Бук. мед. вісник. - 2010. - Т. I, № 2-3. - С. 3-7.

3. Маркін Л.Б. Біофізичний моніторинг плода / Маркін Л.Б, Венцковський Б.М. Воронін К.В. - Львів: Світ, 2013. $-68 \mathrm{c}$.

4. Nyakas C. Hypoxia and brain development / C. Nyakas, B. Buwulda, P.D.M. Luiten // Prog. Neurobiol. - 2013. № 49 (1). - P. 1-51.

\section{ЭХОГРАФИЧЕСКИЕ ОСОБЕННОСТИ РАЗВИТИЯ ЭМБРИОНА У БЕРЕМЕННЫХ С ПЛАЦЕНТАРНОЙ ДИСФУНЦИЕЙ}

\section{И.В. Калиновская}

Резюме. В статье приведены ультразвуковые критерии развития первичной плацентарной дисфункции у беременных. На основе выделенных ультразвуковых критериев изучены последствия и результаты беременности. С 40 беременных в $9(22,5$ \%) при первом ультразвуковом исследовании было обнаруженное отставание копчикотеменного размера (КТР) эмбриона более чем на две недели гестации. Следует отметить, что в четырех из данных наблюдений при КТР эмбриона менее 18 мм все беременности закончились непроизвольным выкидышем. В то же время при КТР более 18 мм ни в одном наблюдении (5) не состоялось непроизвольного прерывания беременности. Значения КТР эмбриона наиболее информативны для прогноза течения и результата гестационного процесса в первом триместре беременности. Брадикардия эмбриона/плода является ультразвуковым признаком, который указывает на возможность патологического результата гестационного процесса у женщин с привычной потерей беременности, так и с проявлениями плацентарной недостаточности.

Ключевые слова: эмбрион, брадикардия, тахикардия, плодное яйцо.

\section{ECHOGRAPHIC FEATURES OF THE EMBRYO GROWTH IN PREGNANT WOMEN WITH PLACENTA DYSFUNCTION}

\section{I.V. Kalynovska}

Abstract. The article presents ultrasonic criteria of development of primary placental dysfunction in the pregnant. On the basis of the selected ultrasonic criteria, the consequences and results of pregnancy have been studied. At the first ultrasonic examination 9 out of 40 pregnant women $(22,5 \%)$ had lagging of the crown-rump length (CRL) of the embryo for more than two weeks of gestation. It should be noted that in four of these observations with CRL of the embryo less than 18 $\mathrm{mm}$ all pregnancies ended with an involuntary miscarriage. At the same time, when the CRL was more than $18 \mathrm{~mm}$ in none of the observations any follow-up (5) was involuntary termination of pregnancy. The CRL values of the embryo are most useful for prognosis and outcome of the gestation in the first trimester of pregnancy. Bradycardia of the embryo / fetus is ultrasonic evidence which points to the possibility of a pathological result of gestation in women with habitual loss of pregnancy, and the manifestations of placental insufficiency.

Key words: embryon, bradycardia, tachycardia, ovum.

Higher State Educational Institution of Ukraine "Bukovinian State Medical University" (Chernivtsi)

Рецензент - проф. Ю.М. Юзько
Buk. Med. Herald. - 2015. - Vol. 19, № 4 (76). - P. 75-77

(C) І.В. Каліновська, 2015 